研究課題別評価

1 .研究課題名 :生体の力学的信号に基づくコミュニケーション

2 .研究者氏名 :小池 康晴

ポスドク研究員 閔 庚甫(シン キョンボ) 研究期間 :2001.4.1〜2003.9.30)

3 . 研究の狙い:

人間と機械のインタフェースを考える場合、機械の設計段階で如何に人間の特性を考えてデバイ スを作るかて操作性が大変異なる。インテリジェンはヒューマンインタフェースとは、

(a) 人間が機械の特性を感じることかできる。

(b) 機械が人間の特性を感じることかできる。

これら両方が実現されてはじめて成り立つ。

インテリジェントデバイスとして、自動運転が考えられる。現在、自動運転が行われている物の一 つとして、飛行機の操縦があるが、今後は、自動車の運転などもITS の進歩とともに実現されてくるも のと予想される。しかし 自動操縦の結果と人間の行う操作が同じであれば問題ないが、人間が自動 操縦に逆らつた操作をしようとした時はどのようにするかは二つに別れる。一つ、自動操縦を優先さ せる、もう一つは人間の操作を優先させることである。自動操縦のアルゴリズムが複雑になればなる ほど人間にとって、どうして自動操縦の操作が生成されたのか理解できない。どうして生成されたの か理解できなければ、弚の操作の後、機体がどのように操作されるのかを予想することもできない。 人間の脳には制御対象の結果を予想するモデルと、結果を生み出した操作入力を予想するモデルが 产れ光れ存在すると考えられる。簡単のため、前者を推定モデル、後者を生成モデルと呼ぶことにす る。

運動の学習は、これら二つの内部モデルを如何にうま〈獲得するかという問題に置き換えることが できると考えている。さらに、運動の学習だけでなく高次の機能であるコミュニケーションも、推定モ デルと予測モデルを組み合わすことで実現していると考えている。たとえば、(a)の人間が機械の特性 を感じるということは、機械の内部モデルを人間か理解することになり (b)の機械が人間の特性を感 じるということは、人間の内部モデルを機械か理解することである。人間同士のコミュニケーションで は、あることを言えば、相手がどのように感じるのか結果を予測し、また、このように感じてほしい ので、どのように言えば良いか」を考え、言葉を生成することができてはじめて会話が成立する。この ように、協調して作業を円滑に行うためには、人間同士だけでなく人間と機械 扱う道具) とか理解し あい、適応的に順応する仕組みを構筑する必要がある。例えば、初心者にとっては、熟練者のように 滑らかに運動を行うことよりも、確実に目的を達成することに主眼を置くと思われるので、例えば、関 節のインピーダンスを高くして自由度を下げて操作を簡単にし、熟練者は、できるだけ関節のインピー ダンスを下げて自由度を高く、滑らかて速し操作を実現させることが゙きるデバイスの作成を目指 す。

4 . 研究結果 :

4.1 筋電信号からのインピーダンス推定

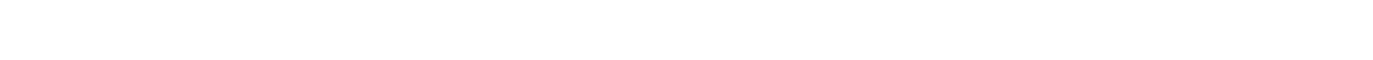


動指令の 1 次式と近似し、運動指令の 2 乗の項までを含んでトルクを計算する数式モデルを 考える。光の式の各パラメータを推定した結果、下图のように、計測したトルクとほほ等しいト ルクを推定することかできた。さらに、静止中のスティフネス棈円体を計算すると、これまでマ ニピュランダムを用いて計算してきたスティフネスとほぼ同樣の性質を持っていることが分かっ た。
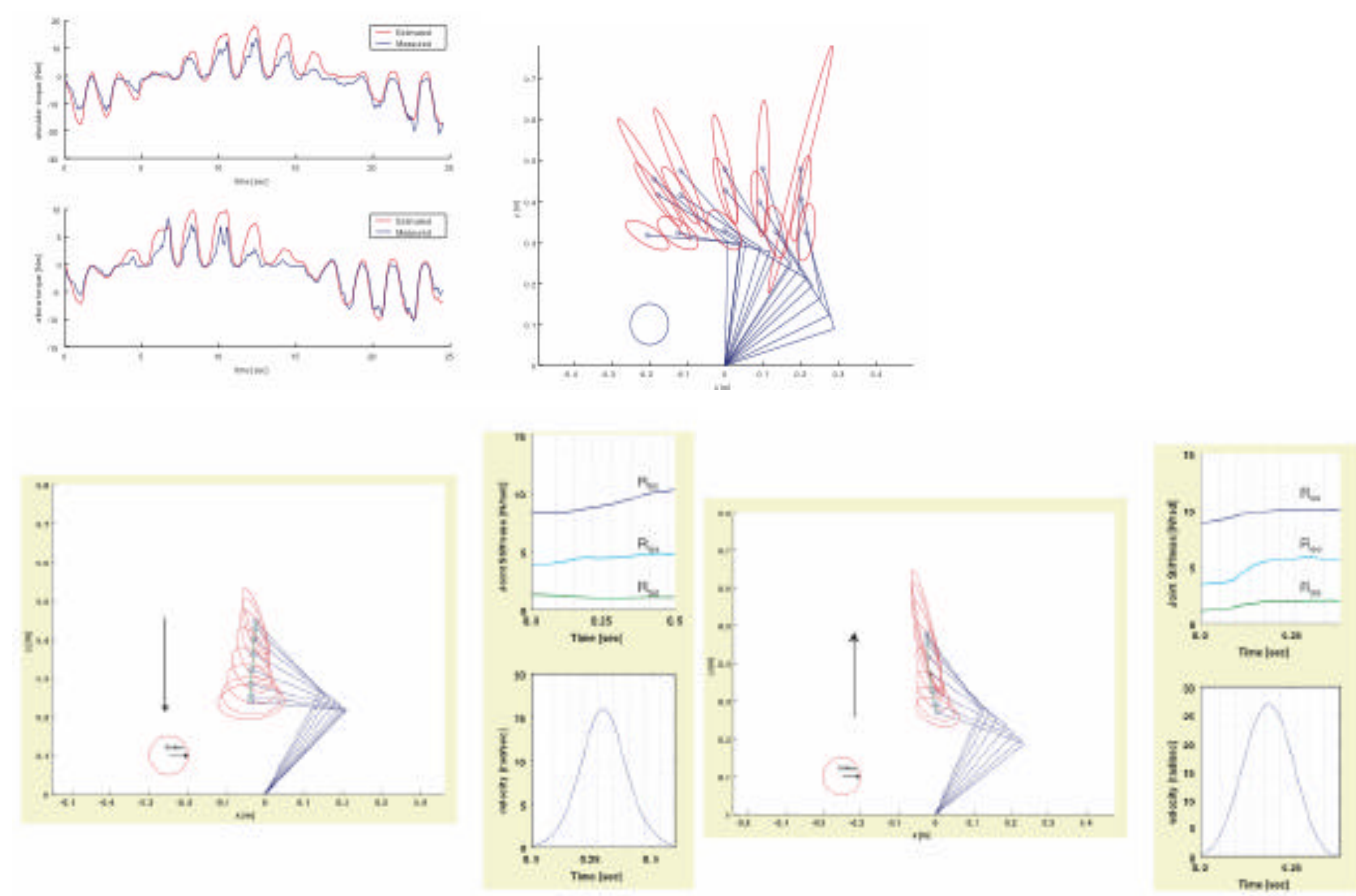

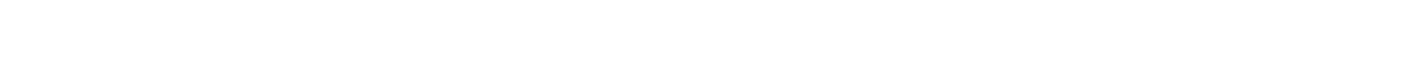
上図のように、運動中のスティフネスの変化を時々刻々と調べことができた。

4.2 感覚入力情報と内部モデル獲得に関する心理物理実験

(1).Size-Weight illusion における重さの予測と知覚 認識

同じ重さであっても大きさが異なると小さい物体を重〈感じる。この原因を探るため、物を持 つときの腕の動きや筋電信号を計測した。また、計測した筋電信号から筋肉の活動を表しス ティフネスと相関がある総活性度 TCL)を計算した。下图は、左が最初に物体を持ち上げたと き、右が重さが同じと答えた 20 回目の記録である。重さが異なると答えたときは、物を持つ前 から重さの予測に応して腕を固くしているとが分かった。
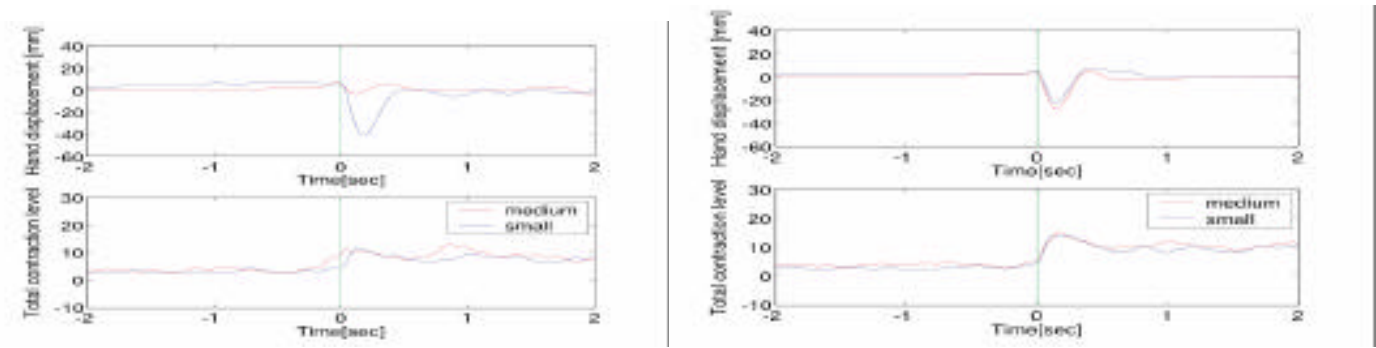

(2).Fitts' law と筋肉の活動

運動速度と精度の間には、Fitts' law と呼ばれる法則かあることが知られている。具体的に は、難しさが大きくなればなるほど、運動時間が長くなるというものである。 
また、同時に計測した筋電信号を計測したところ、運動が終わったあと、筋肉の活動が徐々に 低下していた。このことから、運動の終わりで、同時活性化が起こっていることが示唆された。 この結果は、これまて運動計画の理論として提案されている終端誤差分散最小規範では、説 明かできない現象である。また、終端の精度を求めたときは、求めないときと比較して運動終 端ての筋肉の総活性度が増加している傾向にあることが分かつた。

4.3 強化学習を用いた筋肉骨格系のモデル作成

筋肉の付着位置やモーメントアームなど、筋肉骨格系のパラメータを調整し、精度の高い筋 肉骨格系のモデルを構築した。このモデルに、実際に計測した筋電信号を入力させ、出力で ある関節トルクを比較したところ、精度よ推定できることが分かった。
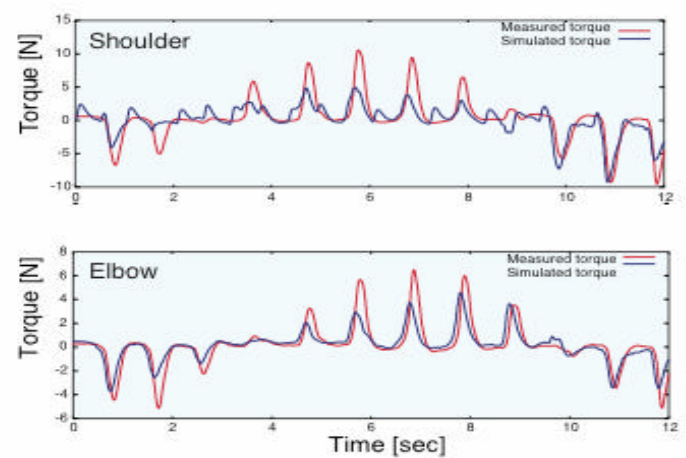
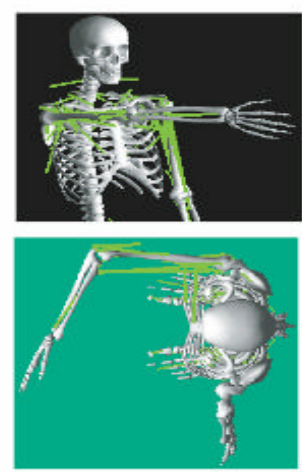

さらに、強化学習により、2関節 6 筋のモデルを用いて、鉛直面内の姿勢制御が可能になつ た。

4.4 筋電信号とハプティックデバイスによる双方向通信ヒューマンインタフェース装置の作成 (1).電気刺激による教示

カをどのくら出したらよいのかを他人に教えるときに、たとえば、習字を習うときのように 先生に手を持ってもらって力の大きさを教えてもらう場合と、電気刺激により筋肉を収縮させ 力を発生させたときで、力を再現した結果を比較した。

その結果、手を使って受動的に力を感じるときよりも、電気刺激により筋肉が活性化して、筋 紡鍾などのセンサにより筋張力を計測した場合の方が再現性が良かつた。このことから、ヒュ 一マンインタフェースとして、双方向のデバイスを考えたとき、電気刺激は有効な手法であるこ とが確認された。また、スティフネスについても同樣の実験を行い、電気刺激によりスティフネ スも定量的に教示可能であるとが分かつた。

(2).筋電信号を通信するヒューマンインタフェース装置

VR 技術を用いて作成し実験装置を用いて、落下してくるボールを手の位置にあるカーソル イ゚ドル)て打つ、パドリンク実験を行った。パドルの硬さを筋電信号に応してリアルタイムに変 化させることで、パドルの動きだけナてなな打つときの硬さを調節して同し高さにボールを打つ タスクを実現した。これは、現実世界では起こりえないが、ラケットの弦の強さをリアルタイムに 変化させることに対応している。今後は、評価実験を行い、より良いインタフェースの設計につ なげていきたい。 


\section{5 .自己評価 :}

最初に考えていた 4 つ目標は、ほぼ達成できたと感じている。一番の成果は、筋電信号だけ から定量的に正しいと思われるスティフネスを推定する方法を確立したことである。この成果によ りこれまで分かっていなかった心理物理現象の解明につながった。さらに、今後、ヒューマンイン タフェースなどへの応用にもつながっていくと思われる。また、ポスドク研究員は、他の研究費で は予算的に確保が難しいため、個人の研究を行うために長期的に契約が可能なこの制度は大変 有用であつた。

\section{6 .研究総括の見解 :}

力学的なコミュニケーションとい泣場から、介護ロボットなどの協調的な力学的インターフェイ ス作成のために必要な筋電位からのスティフネスの正しい推定方法を確立した。人が機械を感じ 機械が人を感じるという最初のコンセプけ基本的な実現可能性を証明したことは評価できる。基 本的なものの周りにあることや応用展開、特に機械システム側の研究に更なる進展を期待した い。

\section{7 .主な論文等 :}

\section{論文誌}

1. J aehyo Kim, Makoto Sato, Yasuharu Koike (2002). "Human Arm Posture Control Using the Impedance Controllability of the Musculo- Skeletal System Against the Alteration of the Environments." The Institute of Control, Automation and Systems Engineers 4(1) 4348.

2. 金 載㷛, 洪 性寛, 佐藤 誠, 小池 康晴 (2002). "SPIDAR を用いた size- weight illusionの検 証." 日本バーチャルリアリテ学会論文誌 7(3), 347? 345.

3. 小池 康晴, 広瀬 秀顕, 飯島 敏夫 2003).筋電信号を用いた腕の運動制御.日本神経回路 学会誌,10(1),2- 10

他 1 件

\section{国際会議 口頭発表)}

1. J aehyo KIM and Yasuharu KOIKE (2001). Human Arm Posture Control Using the Impedance Controllability of the Musculo- Skeletal System against the Alteration of the Environments. Proceedings of the 32nd ISR(International Symposium on Robotics), Seoul, Korea.

2. 2.Y.Koike, O. Shimada, T. Shin, M. Sato R002). DIRECT ARM IMPEDANCE ESTIMATION USING SURFACE EMG SIGNALS, Neuroscience 2002. Orlando, Florida, USA.

3. Akihiko SHIRAI, Shoichi HASEGAWA, Yasuharu KOIKE and Makoto SATO (2003). Trangible Playroom. SIGGRAPH2003, SIGKIDS, San Diego.

他 24 件

\section{特許}

1. 出願番号 特願 2002-212344,発明者 :小池康晴, 発明の名称 運動学習装置,出願日 2002 年 7 月 22 日.

2. 出願番号 :特願 2002-236024,発明者 :小池康晴、嶋田修, 
発明の名称 :インピーダンス測定装置および運動学習支援装置, 出願日 2002 年 8 月 13 日. 